\title{
O estereótipo, a discriminação e o discurso de resistência presentes em memes referente aos povos da Amazônia
}

\author{
The stereotype, the discrimination and the discourse of resistance present in memes \\ concerning to the peoples of the Amazon
}

\author{
Geovânia de Souza Andrade MACIEL* \\ Universidade Federal de Rondônia (UNIR) \\ Lusinilda Carla Pinto MARTINS** \\ Universidade Federal de Rondônia (UNIR)
}

\begin{abstract}
RESUMO: Com o intuito de romper as relações de poder existentes na produção de conhecimentos eurocêntricos, pensadores como Bhabha, Fanon, Hall and Spivak, procuraram desconstruir as ideias produzidas pelos países dominantes e valorizar sistematicamente as produções marginalizadas. Na América Latina, o Pós-colonialismo (ou pensamento decolonial) teve importante recepção no final da década de 1980. Baseado nas contribuições desses teóricos da decolonialidade, o artigo procura mostrar alguns exemplos de estereótipos e discriminação presentes em Memes referentes aos povos da Amazônia e, consequentemente, apresentar o ciberespaço como um ambiente aberto de comunicação contra a subalternidade, o que proporciona ao sujeito articular-se, expressar-se e ser ouvido; e não mais conviver com a passividade da exclusão social. A ênfase desse trabalho estará na análise de Memes (termo que surgiu com Richard Dawkins em 1976), de maneira a evidenciar que os discursos meméticos se propagam na construção e desconstrução da identidade do Outro da Amazônia.
\end{abstract}

PALAVRAS-CHAVE: Estereótipo. Discriminação. Decolonialidade. Amazônia. Memes.

ABSTRACT: In order to break the power relations that existed in the production of Eurocentric knowledge, thinkers such as Bhabha, Fanon, Hall and Spivak sought to deconstruct the ideas produced by the dominant countries and to systematically value marginalized productions. In Latin America, Postcolonialism (or decolonial thinking) had an important reception in the late 1980s. Based on the contributions in these theorists of decoloniality, the article seeks to show

\footnotetext{
Mestra em Letras pela Universidade Federal de Rondônia (UNIR), Porto Velho/RO. E-mail: geovania.maciel@ifro.edu.br

Doutora em Educação Escolar. Docente do Programa de Pós-graduação em Letras da Universidade Federal de Rondônia (UNIR). E-mail: lcarla22@gmail.com.
}

Revista Moara, n. 54, ago-dez 2019 ISSN: 0104-0944

Recebido em 02/08/2019

Avaliado em 22/12/2019 
some examples of stereotypes and discrimination present in Memes concerning the people of the Amazon, and consequently, presenting cyberspace as an open communication space, which allows the subject to articulate himself, express himself and to be heard; and no longer living with the passivity of social exclusion. The emphasis of this work will be on the analysis of Meme (a term that emerged with Richard Dawkins in 1976), in order to show that memetic discourse propagate in the construction and deconstruction of the identity of the Other in the Amazon.

KEYWORDS: Stereotype. Discrimination. Decoloniality. Amazon. Memes.

\section{Introdução}

Na América Latina, o Pós-colonialismo teve importante recepção no final da década de 1980, aqui sendo chamada como pensamento decolonial. Podemos citar como referência de produção decolonial a obra O local da cultura, de Bhabha (2013), que problematiza a maneira depreciativa como o Outro Colonizado é caracterizado pelo discurso do colonialista Europeu. Podemos aludir também a obra Pode o Subalterno falar?, de Spivak (2010), que destaca o implacável descentramento do sujeito, questionando as formas de representação do Outro. As duas produções decoloniais admitem que discursos hegemônicos, referenciados num contexto global, corroboram para negar a heterogeneidade dos sujeitos, além de criar imagens estereotipadas e discriminatórias de determinados grupos minoritários.

Sob a ótica pós-colonial, é possível perceber as relações de embates existentes nos discursos e o quanto as palavras atuam como poderosas forças de subalternidade. $\mathrm{Na}$ atualidade, a cibercultura manifesta-se na vida contemporânea na dimensão tecnológica, social, cultural e epistemológica, de tal maneira que atitudes de embates se tornam práticas constantes em ambiente digital, por meio de representações simbólicas ou não. De certo modo, os autores Champangnatte e Cavalcanti (2015, p. 317) em seus estudos confirmam a ideia proposta por este artigo ao dizerem que a cibercultura:

não apenas destrói hierarquias e fronteiras, mas também as institui em um processo complexo de "des-re-territorializações", o que possibilita aos indivíduos/coletivos estarem imersos em uma maior flexibilidade social, em uma organização fluida com papéis menos rígidos e lugares sociais intercambiáveis. 
Sabe-se que os processos históricos determinaram um olhar colonial sobre a população da Amazônia. Assim, em tempos atuais, muitos ainda visualizam seus habitantes como seres diferentes por fazerem parte de um ambiente exótico representado pelo imaginário do europeu colonizador diante da sua hegemonia discursiva abordada em seus primeiros relatos, cartas, e outros textos da época colonial, que até hoje transmitem uma descrição imaginária persistente.

Igualmente, na busca por uma relação amistosa entre as diferentes culturas, o desenvolvimento tecnológico e o crescimento da liberdade das produções literárias se fizeram como meios imperiosos para permitir a expansão de ideias que demarcam um

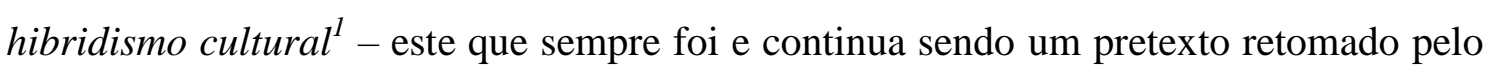
colonizador como estratégia para aprisionar o Outro.

De tal maneira, este artigo utilizará algumas exemplificações de Memes que anunciam um imaginário representativo do/pelo povo da Amazônia, ao considerar as especificidades na liberdade de utilização do ciberespaço ${ }^{2}$ tendo os Memes como exemplo prático de discurso que se propaga na construção e desconstrução das identidades.

\section{Os memes: da origem a atualidade}

O conceito de meme surgiu em 1976 com a publicação do livro O Gene Egoísta do biólogo evolutivo, etólogo e escritor britânico Richard Dawkins. Mas vale lembrar que o conceito inicial abordado por Dawkins aproximava meme ao sentido comportamental de gene e dos princípios darwinianos. No último capítulo do livro, intitulado Memes: os novos replicadores, o autor afirma: "Precisamos de um nome para

\footnotetext{
${ }^{1}$ Ver A Identidade Cultural da Pós-Modernidade do escritor Stuart Hall (2006): um teórico cultural e sociólogo jamaicano que viveu e trabalhou na Inglaterra, transitando constantemente entre diferentes culturas. No capítulo 6 dessa obra - Fundamentalismo, diáspora e hibridismo - o autor apresenta ser a globalização a grande responsável pelos dois argumentos contraditórios explicitados: ora identidades híbridas, ora identidades homogeneizadas. Nesse sentido, Hall amplia a compreensão de hibridismo ao sinalizar que as identidades culturais são híbridas e, consequentemente, movidas por mudanças, encontros e desencontros. Dessa forma, percebe-se a impossibilidade de termos uma identidade, mas que somos compostos por uma identificação, passível de mudança e transformação.

${ }^{2}$ Conforme Champangnatte e Cavalcanti (2015, p. 314), o "ciberespaço tem sido o lugar de interação e expressão para variadas atividades que envolvem coletivos de resistência, que têm como finalidade difundir suas reivindicações na tentativa de perfurar os mecanismos políticos/ideológicos impostos pela grande mídia hegemônica da indústria cultural”.
} 
o novo replicador, um substantivo que transmita a ideia de uma unidade de transmissão cultural, ou uma unidade de imitação " (DAWKINS, 1979, p. 122).

Sobre essa concepção replicadora, Dawkins exemplifica memes da seguinte maneira:

\begin{abstract}
Exemplos de memes são melodias, idéias, "slogans", modas do vestuário, maneiras de fazer potes ou de construir arcos. Da mesma forma como os genes se propagam no "fundo" pulando de corpo para corpo através dos espermatozóides ou dos óvulos, da mesma maneira os memes propagam-se no "fundo" de memes pulando de cérebro para cérebro por meio de um processo que pode ser chamado, no sentido amplo, de imitação. Se um cientista ouve ou lê uma idéia boa ele a transmite a seus colegas e alunos. Ele a menciona em seus artigos e conferências. Se a idéia pegar, pode-se dizer que ela se propaga, si própria, espalhando-se de cérebro a cérebro ( DAWKINS, 1979, p. 122-123).
\end{abstract}

Enquanto o gene é uma unidade biológica que procura se propagar por organismos vivos, o termo meme surge como ideias, discursos e tantas outras formas de manifestações que se espalham na sociedade de maneira célere. $\mathrm{O}$ estudo desse conceito é denominado Memética e tem como base o raciocínio de que, da mesma maneira como os genes determinam a transmissão de suas cópias às gerações futuras, as ideias também vivem em competição entre si para conseguir dominar o maior número de cérebros. E só são possíveis entre nós seres humanos porque diferente dos animais possuímos a capacidade de imitar (TEIXEIRA, 2003).

O sentido de Meme ampliou-se a ponto de significar qualquer representação mental (superstições, crenças, doutrinas, teorias, moda, entre outros) e só recentemente os cientistas estão chegando a um consenso sobre a Memética enquanto ciência. Nas relações públicas e na publicidade, os memes da internet têm sido utilizados como uma forma de marketing viral para seus serviços, principalmente em razão do seu custobenefício e de sua modicidade.

No campo da informática, a expressão passou a ser chamada de Memes de Internet, e se refere a qualquer ideia ou conceito que se espalha aceleradamente através da Web por intermédio de sites de notícias, e-mails, blogs, whatsApp, entre outras fontes de informação. Outro aspecto significativo é a sua característica de anonimato, pois geralmente não traz assinatura, o que impossibilita a responsabilidade jurídica do autor. Assim, quando ocorre a divulgação de um meme agressivo, preconceituoso e discriminatório, só é possível responsabilizar os internautas que compartilham. 
Sabe-se que os memes da internet mobilizam sentidos humorísticos e pejorativos e grande parte deles propagam relações de desigualdades (superior/inferior); mas por outro lado, sob uma perspectiva da crítica decolonial, sustentada por autores como Fanon, Bhabha e tantos outros a respeito do desafio da descolonização, os Memes podem funcionar como ferramenta de ressignificação de uma cultura marginalizada quando são colocados como lugar de interação coletiva de resistência na tentativa de transpor os mecanismos políticos e ideológicos impostos pela supremacia da Indústria Cultural.

\section{Olhar do Outro: a colonialidade do poder/saber/ser}

Os estudos da crítica colonial não quiseram (e nem conseguiriam) desfazer todo o processo histórico e cultural produzido pela colonização ocorrida em nosso país. Isso é certo se levarmos em consideração a influência quantitativa Europeia na constituição híbrida cultural existente no Brasil. Na verdade, trata-se de perceber que o conceito de decolonialidade volta-se para buscar modos de pensar e ser que consigam resistir às feridas marcadas a ferro e fogo não apenas nos processos de dominação política e econômica, mas, sobretudo, aprofundar as problemáticas que interfiram na subjetividade das relações interligadas, de maneira especial, aos pressupostos etnocêntricos relativos à classe, raça e gênero, utilizados repetidamente pelo colonizador como meio de subalternizar, estereotipar, discriminar e inferiorizar culturas díspares.

Os estudos de Fanon e Bhabha assim reconheciam a fundamental importância do reconhecimento e recuperação das tradições culturais e históricas do povo reprimido e da consequente percepção de que seus saberes são tão valiosos quantos os de origens não colonialistas. Contudo, faz-se relevante compreender "os perigos da fixidez $z^{3}$ e do fetichismo ${ }^{4}$ de identidades no interior da calcificação de culturas coloniais para

\footnotetext{
${ }^{3}$ No decorrer de seu livro Bhabha (2013) nos apresenta um conjunto de conceitos com o intuito de analisar a relação entre racismo e cultura, tais como: autoridade colonial, discurso colonial, ambivalência, fetichismo, fixidez, estereótipo, diferença colonial. O autor reafirma o perigo da fixidez: "A fixidez, como signo da diferença cultural/histórica/racial no discurso do colonialismo, é um modo de representação paradoxal: conota rigidez e ordem imutável como também desordem, degeneração e repetição demoníaca" (BHABHA, 2013, p. 117)

${ }^{4}$ Ao falar de fetichismo Bhabha (2013, p. 130) assevera que: "O fetiche ou estereótipo dá acesso a uma "identidade" baseada tanto na dominação e no prazer quanto na ansiedade e na defesa, pois é uma forma de crença múltipla e contraditória em seu reconhecimento da diferença e da recusa da mesma".
} 
recomendar que se lancem "raízes" no romanceiro celebratório do passado ou na homogeneização da história presente.” (BHABHA, 2013, p. 31). A atividade negadora, portanto, causa estranheza e deve estar assegurada por um equilíbrio constante para que o decolonialismo não reincida em uma nova forma de colonialismo.

Sob essa ótica, as ideias de decolonialidade são importantes por nos fazer perceber que os conflitos de poder-sabe-ser continuam presentes. Isso traz a tona pensar que o ser humano tem em sua natureza um espírito dominador, tanto que muitos dos colonizados na primeira oportunidade que tem de se fazer superior, não pensam duas vezes em praticar tal ação. Poderia assim afirmar que a crítica decolonial funciona também como um princípio para expandir-se a prática da alteridade humana, visto que todos os seres interagem e interdependem do outro a partir de suas diferenças.

Com o advento da internet, os receptores (antes passivos) assumiram também o papel de agentes emissores, alargando a teia comunicacional anteriormente restrita apenas aos meios de comunicação de massa que auxiliavam a fixidez do discurso colonial na construção ideológica da alteridade.

$\mathrm{Na}$ tentativa de demonstrar que os efeitos do domínio colonial não foram estancados quando se concluiu o domínio territorial sob quaisquer colônias, abaixo, serão apresentados alguns Memes que refletem de modo estereotipado e/ou discriminatório os povos da Amazônia sob um olhar colonizador e, em contrapartida, outros memes como resposta rápida - proporcionada pela cibercultura - que nos faz perceber que na atualidade as ambivalências traumáticas do passado, cedem lugar para um novo jeito de reinscrever o estranhamento de culturas.

\section{Os embates: representações das ambivalências presentes nos estereótipos meméticos}

\subsection{O estereótipo como estratégia discursiva de ataque}

\section{Exemplo I:}

Em março de 2014 um vídeo ${ }^{5}$ destacou-se nos meios midiáticos digitais, sendo compartilhado nas plataformas de redes sociais mais populares (como facebook e

\footnotetext{
5 Disponível em: https://noamazonaseassim.com.br/memes-voces-so-sabem-comer-peixe-e-descascartucuma/. Acesso em: 28 mai. 2018.
} 
Twitter): devido ao péssimo atendimento recebido, uma mulher resolveu desabafar sua opinião a respeito dos manauaras - moradores da cidade de Manaus. A visitante, em tom raivoso e pejorativo, ao afirmar que o povo de Manaus só sabia comer peixe e descascar tucumã, despertou o sentimento de revolta em seus interlocutores que, em resposta, elaboraram inúmeros memes sobre o assunto.

Veja na sequência alguns exemplos dos memes produzidos nessa ocasião e uma breve análise referente ao assunto:
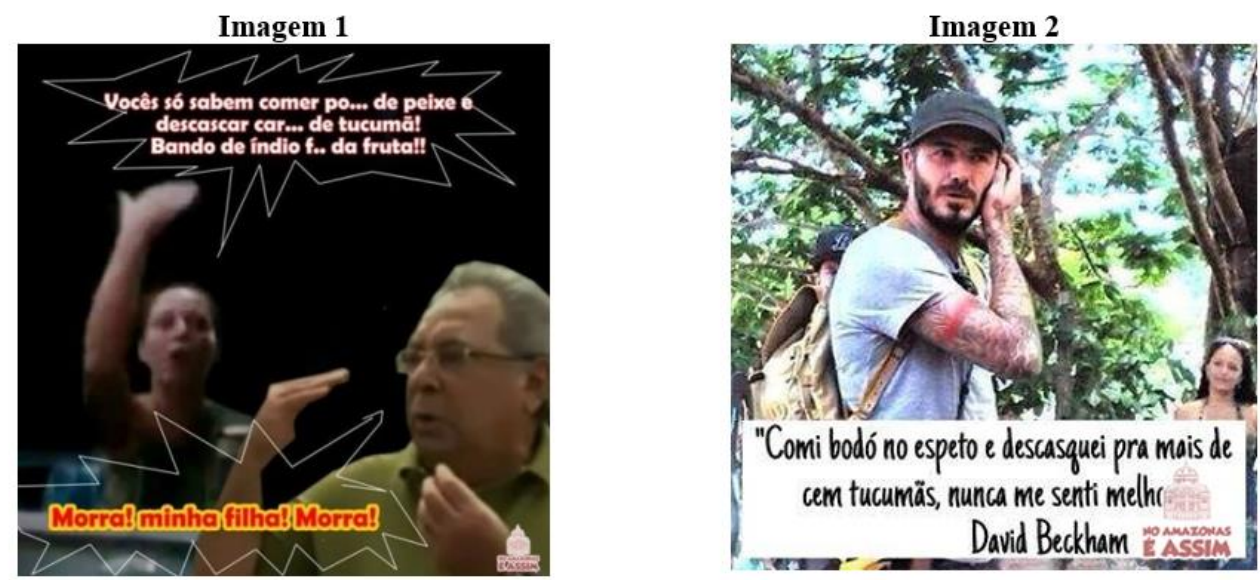

Fonte: Disponível em: https://noamazonaseassim.com.br/memes-voces-so-sabem-comer-peixe-edescascar-tucuma/

Imagem 1: A mulher e sua fala revoltada aparecem na ilustração. Na sequência, a resposta - "Morra, minha filha, morra!" - procura transmitir a indiferença da população em relação ao descaso que a mulher teve em aceitar a diferença do Outro.

Imagem 2: Em rebate ao vídeo, o Meme 2 utilizou uma figura conhecida: David Beckham (ex-jogador de futebol inglês que anunciou sua aposentadoria no final de 2013). Tal estratégia foi para dar maior autoridade à frase que reforça o Meme de Embate: "Comi bodó no espeto e descasquei pra mais de cem tucumãs, nunca me senti melhor". A sentença valoriza a culinária típica da região que fora marginalizada no vídeo.

Retomemos uma alusão trazida por Bhabha ao falar da força da ambivalência (2013, p. 118):

Isto porque é a força da ambivalência que dá ao estereótipo colonial sua validade: ela garante sua repetibilidade em conjunturas históricas e discursivas mutantes; embasa suas estratégias de individuação e marginalização; produz aquele efeito de verdade probabilística e predictabilidade que, para o estereótipo, deve sempre estar em excesso do que pode ser provado empiricamente ou explicado logicamente. 
Observa-se que, ao não ser bem recepcionada em um estabelecimento de Manaus - capital brasileira com um alto número de habitantes indígenas - a mulher utiliza a imitação do discurso colonizador que visualiza os indígenas e seus descendentes como pessoas preguiçosas. Assim, através do acontecido, ela aproveita uma peculiaridade da cultura dos manauaras e produz um efeito de verdade quando generaliza que toda a população apenas sabe comer peixe e descascar tucumã. $\mathrm{O}$ estereótipo é a estratégia discursiva de ataque. Igualmente já afirmara Bhabha (2013, 154-155) que:

Essas articulações contraditórias da realidade e do desejo - vistas em estereótipos, declarações, piadas e mitos racistas - não estão presas no círculo duvidoso do retorno do reprimido. Eles são os resultados de uma recusa que nega as diferenças do outro, mas que produz em seu lugar formas de autoridade e crenças múltiplas que alienam as pressuposições do discurso "civil".

\subsection{O ciberespaço para construção e desconstrução de hierarquias}

\section{Exemplo II:}
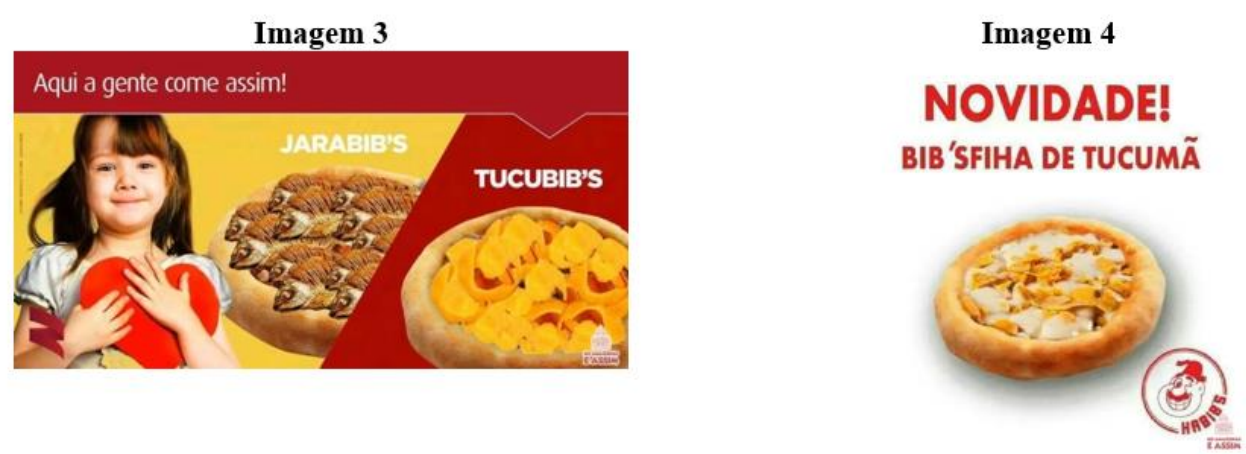

Fonte: Blog no Amazonas é assim. Disponível em: https://noamazonaseassim.com.br/memes-vocesso-sabem-comer-peixe-e-descascar-tucuma/

Imagem 3 e 4: Os Memes foram produzidos utilizando-se do nome de uma rede de restaurantes de comida rápida especializada em culinária árabe (Habib's). De forma irônica e metafórica destaca os aspectos de qualidade/agilidade, contrapondo-se a ideia de preguiça apresentada pela mulher no vídeo em questão.

O ciberespaço na atualidade vem modificar o modo de recebimento dos discursos, pois "emerge como um território sem fronteiras, aparentemente sem controles e hierarquias" (CHAMPANGNATTE; CAVALCANTI, 2015), e da mesma maneira em 
que as ideias são produzidas e distribuídas, são também atravessadas por respostas instantâneas. É o que acontece com os memes apresentados. Se antes o colonizado tinha receios de revidar, às vezes reconhecia sua diferença e procurava recusá-la utilizando-se da imitação do outro $\left(\right.$ mímica $\left.^{6}\right)$; agora o ciberespaço colabora para destruir hierarquias e as 4 imagens apresentadas anteriormente despertam para $o$ sentimento de inaceitabilidade de um estereótipo que atravessa o tempo.

\subsection{Os efeitos-identidade: herança colonial confrontada}

Sabe-se que mesmo na atualidade, a Amazônia continua a despertar questionamentos e inquietações no imaginário de quem a desconhece. Gondim, em sua obra A invenção da Amazônia (1994, p. 38), explicitara que o novo concebe uma diversidade que causa insegurança, então, representá-lo através da monstruosidade e/ou de maneira estigmatizada é a maneira de assegurar a supremacia.

As heranças do histórico abordado em seu livro permanecem marcadas por uma visão estereotipada da região dos povos amazônicos; estes são demasiadamente representados como personalidades selvagem, rural, rude e o ambiente descrito como precário. É o que podemos perceber nas imagens 5 e 6 apresentadas a seguir:

\section{Exemplo III}
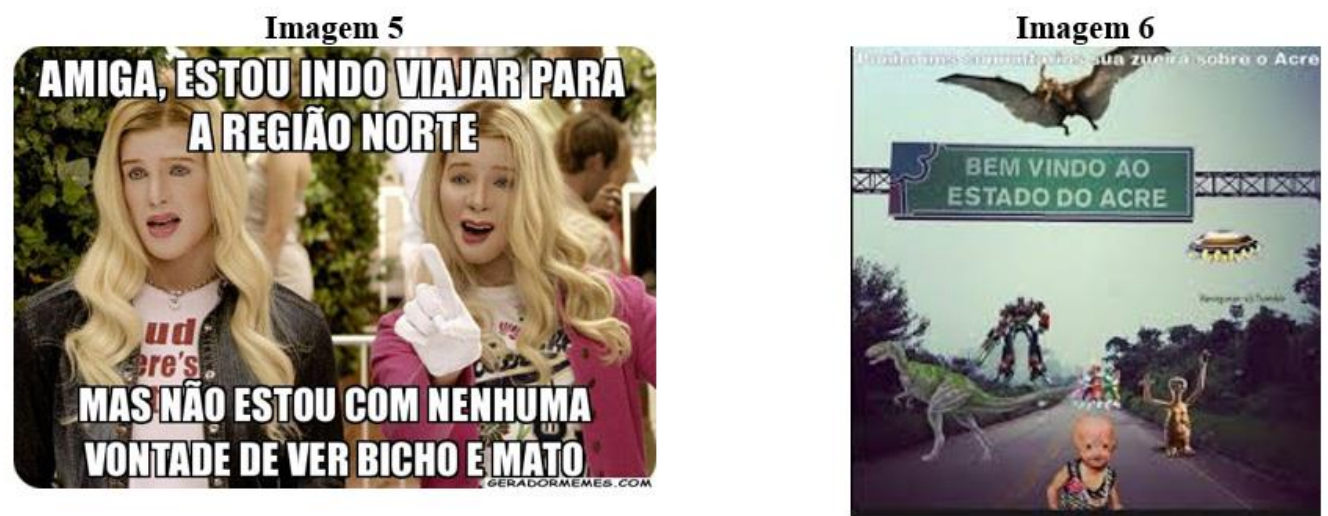

Fonte: Disponível em: https://noamazonaseassim.com.br/memes-voces-so-sabem-comer-peixee-descascar-tucuma/

\footnotetext{
${ }^{6}$ Ver capítulo IV - Da mímica e do homem: a ambivalência do discurso colonial - do livro $O$ Local da Cultura de Homi Bhabha (2013). Nele o autor esclarece a mímica como uma estratégia induzida pelo colonizador que funciona como um acordo irônico que ocasiona "efeitos-identidade".
} 
Para corroborar na reflexão vale trazer a obra da escritora indiana Spivak que apresenta o sujeito subalterno na definição daquele ser pertencente "às camadas mais baixas da sociedade constituídas pelos modos específicos de exclusão dos mercados, da representação política e legal, e da possibilidade de se tornarem membros plenos no estrato social dominante" (SPIVAK, 2010, p. 12).

Nos exemplos aqui expostos são subalternizados aqueles que se encontram no contexto amazônico fruto da miscigenação de etnias e do multiculturalismo. E se propaga até os dias atuais o olhar externo da invenção a respeito da Amazônia: jaz a ideia de que os habitantes dessa região mantêm um modo de vida completamente tradicional, primitivo e isolado do seu tempo.

\subsection{Meme: produção discursiva de reexistência dos povos amazônicos}

Fanon (2008, p. 38) nos alertava que "a sociedade, ao contrário dos processos bioquímicos, não escapa a influência humana. É pelo Homem que a sociedade chega ao ser. O prognóstico está nas mãos daqueles que quiserem sacudir as raízes contaminadas do edifício". De tal modo, sabemos que a mídia tem o poder de formar opiniões e ditar modelos a serem seguidos. E se essa revolução do espaço virtual disponibiliza um nível acelerado de compartilhamentos e predispõe autonomia aos sujeitos, percebe-se que o meme na mesma proporção que alastra crenças e valores antigos, também sofre alterações e ganha forças para se espalhar com novos significados. Podemos tomar emprestado o termo reexistência cunhado por Souza (2009) e afirmar que: a prática do discurso de resistência através dos memes tem contribuído para a produção de uma reexistência dos povos da Amazônia.

Diante do fluxo intensivo na disseminação de informação os memes contribuem para que os grupos promovam intervenções quase imediatas às subalternidades diversas impostas pelas relações sociais. $O$ que se percebe na atualidade é que o discurso anteriormente ditado por pessoas que desconheciam as verdadeiras características da região, agora passa a ser utilizado como um discurso de defesa, um orgulho em expor

que é diferente, nem que para isso recorra aos exageros. É o que observamos nos memes 7 e 8 : 


\section{Exemplo IV:}

Imagem 7

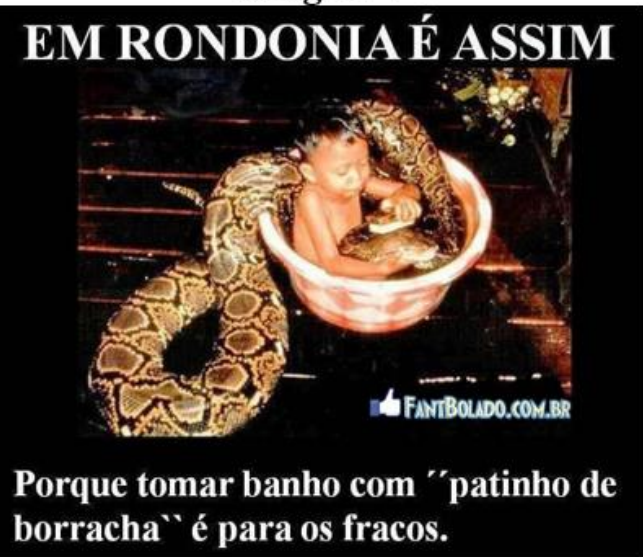

Imagem 8

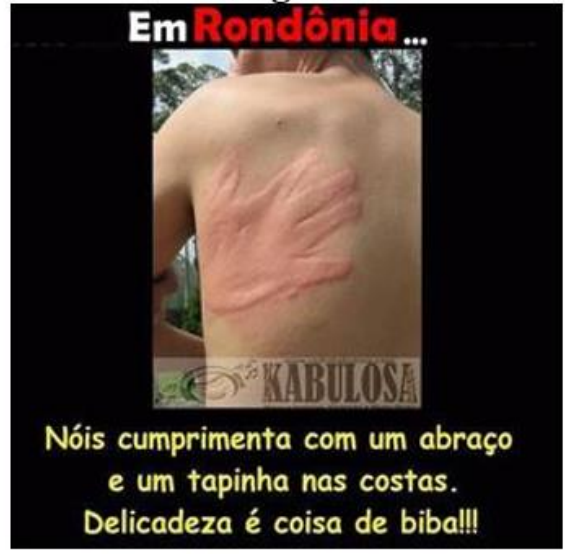

Fonte: Blog fant bolado. Disponível em: http://fantbolado.blogspot.com/2012/03/em-rondonia-o-baratoe-loko-porque.html

Os memes 7 e 8 são produzidos em respostas aos estereótipos que permeiam pensamentos semelhantes aos das representações das figuras meméticas 5 e 6 . Também utilizam da ironia e da agressividade. Há uma facilidade de o subalterno jogar com as mesmas cartas daquele que o inferioriza. A ilustração 5 desvalorizou o ir até a região Norte ao descaso de ver somente bichos e mato. No meme 7 isso é motivo de orgulho, reconhece que o ambiente é composto por rica fauna e flora e reforça (mesmo que hiperbolicamente) que o convívio com os animais faz do ser da Amazônia um Forte.

O meme 6 exemplifica a representação do estado do Acre em forma de piada há diversas cópias que retransmitem a ideia apresentada por este meme (ao simulá-lo como um lugar totalmente desconhecido, supostamente sem televisão, carro, internet...). No intuito de reforçar a ideia de que os acreanos estão presos ao passado se utilizam da imagem do dinossauro e de seres extraterrestres aludindo que a tecnologia não tivesse alcançado tal estado brasileiro.

A crítica decolonial procura recuperar a voz subalterna contra as narrativas do eurocentrismo. A pergunta trazida no livro de Spivak Pode o subalterno falar? nos induziu a pensar na ambiguidade dos sentidos da palavra pode (Sentido 1.: O subalterno tem o poder, a liberdade para falar? / Sentido 2.: O subalterno consegue falar? Tem habilidades para discorrer seus pensamentos?) e igualmente nos faz refletir que os 
memes fortalecem ambos os sentidos: o indivíduo tem liberdade para falar e consegue praticar esse direito. A prática de resistência/reexistência é facilitada pela característica da anonímia (ausência de autoria) dos memes, visto que o subalterno pode utilizar o meme que melhor expressa seu grito de liberdade com certa segurança de que não será reprimido/torturado por proclamar suas angústias e inquietações. Pode ainda a partir dos memes representar os valores pessoais e/ou grupais, reforçando as relações interpessoais na luta por um ideal comum.

A evolução da sociedade está marcada pelas constantes inovações tecnológicas que exigem mentes flexíveis e dinâmicas no tratamento com o Outro, que respeitem as dimensões sócio históricas e culturais. A partir desta visão este artigo procurou analisar os memes apresentados e colocá-los no embate cultural na contemporaneidade, como um instrumento linguístico de interação comunicacional capaz de corroborar na luta em romper as barreiras na desconstrução de estereótipos ao povo indígena, ribeirinho, seringueiro, quilombola, entre tantos outros que compõem o multiculturalismo da Amazônia.

\section{Considerações finais}

Considerando as inúmeras leituras e releituras realizadas sobre as teorizações e desdobramentos do pensamento decolonial, o presente trabalho pretendeu apresentar a perspectiva de desconstrução de ideias hegemônicas que inferiorizam os povos amazônicos.

A partir da exemplificação dos memes da internet reafirmou-se que posturas de estereótipos e discriminação estão constantemente ao lado de posturas de resistência na luta pelo respeito ao multiculturalismo amazônico. São os embates do passado que persistem no hoje modificando os instrumentos de ataque, e a produção que é a reexistência do Outro.

De tal maneira procurou-se enfatizar o meme como ferramenta para vencer a subalternidade, já que o mesmo se apresenta como uma unidade de transmissão de cultura e informação. Vale salientar que, diante da instantaneidade proporcionada pela cibercultura, esse gênero multimodal analisado contribui para romper fronteiras e 
hierarquias instituindo um processo de des-re-territorializações diante do compartilhamento de valores culturais na luta pela negação da opressão colonizadora.

\section{REFERÊNCIAS}

BHABHA, Homi K. O Local da Cultura. 2 ed. Tradução: Myriam Ávila, Eliana Lourenço de Lima Reis e Gláucia Renate Gonçalves. Belho Horizonte: Editora UFMG, 2013.

BLOG FANT BOLADO. Em Rondônia o barato é loko! .....Porque tomar banho com "patinho de borracha" é pra os fracos! 2012. Disponível em: http://fantbolado.blogspot.com/2012/03/em-rondonia-o-barato-e-loko-porque.html. Acesso: 28 mai. 2018.

CHAMPANGNATTE, Dostoiewski Mariatt de Oliveira; CAVALCANTI, Marcus Alexandre de Pádua. Cibercultura - perspectivas conceituais, abordagens alternativas de comunicação e movimentos sociais. Revista de Estudos da Comunicação, Curitiba, v. 16, n. 41, p. 312-326, set. /dez. 2015.

DAWKINS, Richard. O Gene Egoísta. Tradução: Geraldo Florsheim, Belo Horizonte: Itatiais; São Paulo: Editora da Universidade de São Paulo. 1979. Disponível em: http://files.nossateca5.webnode.com/200000079-

13926148c1/O\%20Gene\%20Egoista\%20-\%20Richard\%20Dawkins.pdf. Acesso em: 02 jul. 2019.

FANON, Frantz. Pele negra máscaras brancas. Tradução: Renato Silveira. Salvador: Edufba, 2008.

GONDIM, Neide. A Invenção da Amazônia. São Paulo, SP: Marco Zero, 1994.

HALL, Stuart. Identidade cultural na pós-modernidade. Tradução: Tomaz Tadeu da Silva e Guacira Lopes Louro. 11. ed. Rio de Janeiro: DP\&A, 2006.

NO AMAZONAS É ASSIM. O portal de Notícias e Entretenimento do Amazonas. [Memes] Vocês só sabem comer Peixe e Descascar Tucumã. Disponível em: https://noamazonaseassim.com.br/memes-voces-so-sabem-comer-peixe-e-descascartucuma/ Acesso em: 28 mai. 2018.

SOUZA, Ana Lúcia Silva. Letramentos de Reexistência: culturas e identidades no movimento hip-hop. 219 p. Tese (Doutorado em Linguística Aplicada) - Universidade Estadual de Campinas, Instituto de Estudos da Linguagem. Campinas, SP, 2009. Disponível em: http://repositorio.unicamp.br/jspui/handle/REPOSIP/269280. Acesso em: 03 jul. 2019. 
SPIVAK, Gayatri Chakravorty. Pode o subalterno falar? 1. ed. Tradução: Sandra Regina Goulart Almeida, Marcos Pereira Feitosa e André Pereira. Belo Horizonte: Editora da UFMG, 2010.

TEIXEIRA, Jerônimo. O DNA das ideias. Revista eletrônica Super Interessante, 2003. Disponível em: https://super.abril.com.br/ciencia/o-dna-das-ideias/. Acesso em: 28 maio 2018. 